Anna Antczak

DOI: 10.2478/v10241-012-0001-y

\title{
Strategic interests of the European Union
}

\section{ABSTRACT}

Main challenges for the European security policy are caused by the creation of new states, nationalisms and ethnic problems, enforcement of religious fanatics, globalisation of economy as well as a threat of huge migration from poorer parts of the world to Europe. The most important issue, from the perspective of the European role in the world, is the "shift of gravity" - towards Asian countries and new economic powers. The importance and interest in Europe diminishes and floats towards so called Asian Tigers, and Europe seems helpless facing the changes. The article aims at presenting the EU's strategic interests as well as show difficulties in creating common foreign and security policy. Identification of strategic fields of interest of the EU may seem easy and obvious, but the realization of common policy appears to be problematic or even impossible due to too distant objectives of the member states and their particular national interests. Nevertheless, the article discusses specific EU interests in the Middle East, Asia and Africa as well goes into the analysis of EU-NATO (USA) relations and importance of this cooperation.

KEYWORDS: European Union, strategic interests, Common Foreign and Security Policy.

* Correspondence regarding the paper should be sent to: Dr Anna Antczak, Kancelaria Senatu, ul. Wiejska 6, 00-902 Warszawa, e-mail: annique@wp.pl 
STRATEGIC INTERESTS OF THE EUROPEAN UNION:

MIDDLE EAST, SOUTH-EAST ASIA AND AFRICA

It seems that the geostrategic area of the European Union (EU), commonly perceived as "the West", undergoes the civilization crisis. Its dynamics is concentrated almost entirely on consumption ("Western European policy is to prolong high level of life and consumption as long as possible" - Kapuściński, 2007: 160) leaving the question about its role in the world without an answer. Western Europe focuses its attention on itself, refusing to take up concrete actions in other regions. It is rather a shortsighted policy of isolation. The collapse of the bipolar system, destroyed basis for a certain system of values and Europe was not able to build any constructive alternative which would give the continent a new strength. Most efforts are concentrated on establishing the concept of the "European identity" including common foreign, security and defence policy ${ }^{1}$.

Main challenges for the European security policy are caused by the creation of new states, nationalisms and ethnic problems, enforcement of religious fanatics (mainly orthodox Islam), globalisation of economy as well as a threat of huge migration from poorer parts of the world to Europe. The last factor is the reason for European special interest in life conditions improvement in the third world countries to minimize the number of immigrants generating many problems inside the EU (social, political and economic issues due to different culture, social status, value system, etc.). The most important issue, from the perspective of the

${ }^{1}$ Europe began to notice the necessity of working out the European security and defence identity in the eighties of the XX century (European Defence and Security Identity - EDSI concept) - for more information see R. Zięba, Europejska Tożsamość Bezpieczeństwa i Obrony, Wydawnictwo Naukowe SCHOLAR, Warszawa 2000 and R. Zięba, Instytucjonalizacja bezpieczeństwa europejskiego, Wydawnictwo Naukowe SCHOLAR, Warszawa 2001. 
European role in the world, is the "shift of gravity" - towards Asian countries and new economic powers. The importance and interest in Europe diminishes and floats towards so called Asian Tigers, and Europe seems helpless facing the changes.

It also appears that nowadays, the best security guarantee is a subtle network of international political and economic interdependences using different methods, means and ways of action. Globalization causes that states cannot stay indifferent facing any security regime established by other players (Kolodziej, 2005: 35). Taking into consideration the fact that Europe is not threatened by any direct military danger, the EU deals mainly with guaranteeing its own security through actions aiming at solving crises and conflicts out of area - rising the overall level of security (Zięba, 2008: 290-295).

Identification of strategic fields of interest of the EU may seem easy and obvious, but the realization of common policy appears to be problematic or even impossible due to too distant objectives of the member states and their particular national interests. "Culture and national identity, which, broadly speaking, constitute identity of civilization, form coherence, disintegration and conflict in the world after the Cold War" (Huntington, 2003: 15). Huntington claims that the most important differences between nations are not of ideological, political or economic character, but are a matter of culture (Huntington, 2003: 18), which is why "the most violent conflicts break out between Muslim and Asian countries on the one hand, and the West - on the other" due to "mutual influence of Western arrogance, intolerance of the Islam, and Chinese self-confidence" (Huntington, 2003: 307). This is the reason why Middle East and South-Eastern Asia and Africa are the regions of the greatest strategic importance for European security (apart from Russia which is not the issue that will be discussed in this article). Destabilization in the Middle East (growth of organized crime and international terrorism as well as Islamic extremism) with huge individuality of China (re- 
lief from Western influence and decisions) are regarded as the greatest threats for the EU. Western countries, considering only their own solutions as right (especially in the field of economy), try to enforce their supremacy, promoting their own interests and using such powerful international institutions as International Monetary Fund or the World Bank. The EU is aware of the fact that it will be easier to impose own domination and preserve its economic power in a stable and democratic world with free market rules, lacking terrorism of religious fanatic character, as Western countries are able to win over such world using their rules (superiority of economic, technological and social advancement). Otherwise, they will have to work out and employ new methods of pressure, which will mean the necessity to resign from the development dynamics directed mainly at consumption. It all influences the behavior of the Western countries aiming at "preserving their exceptional position and defending their own interests, defining them as the world society interests" (Huntington, 2003: 308).

Taking up a different categorization, Western culture countries, including the EU, are mainly focused on three issues: maintenance of military dominance (nonproliferation and armament control policy are one the tools ${ }^{2}$ ), propagating own political and economic values (democracy, human rights and free market) ${ }^{3}$, and protection of social and cultural integrity - preventing the flow of immigrants and refugees (Huntington, 2003: 312). On the other hand, it is often the case that the above mentioned ideology of propagating democracy and human rights are taken over by economic factors. European consortia put pressure over governments so that they do not destroy relations with Asian coun-

${ }^{2}$ Hidden under the ideas of security and stability in the world, there lies the desire to prevent the spread of weapons of mass destruction, which would undermine the position of the EU and the U.S.

${ }^{3}$ This aspect is especially emphasized in the US policy. 
tries because of "ideological” reasons, as it would slow down economic development (lowering sales and possibilities of investment). Nevertheless, quickly developing Asian countries (especially South-Eastern Asia) begin to cut their dependencies on the EU or USA, so they are less pliant to pressures concerning democracy, human rights or armament issues.

Many experts and scientists claim that the greatest real threat of widely perceived military character for Western countries comes from orthodox and fanatic Muslim countries which expose terroristic tendencies. The biggest tragedies in the European countries in the recent years were generated by terrorist attacks connected with Islamic terrorism. It is then hard not to agree with the thesis stated by Huntington (2003: 362) that "conflicts between the West and Islam do not concern territorial issues as much as they concern broader inter-civilization issues such as proliferation of weapon of mass destruction, human rights, democracy, oil resources control, migration, Islamic terrorism, Western intervention".

A growing problem for the EU is immigration, and the greatest threat comes from Islamic countries. The issue of immigration is not yet a problem for the whole EU, but the process is very dynamic. Nowadays, the greatest number of Muslim immigrants are in France, Germany and the Netherlands, and from the Maghreb countries: in Spain and Italy. The above mentioned matter is strictly connected with another one - broadening of the European Union and accession of Muslim countries - Turkey in the first row. There lasts a lively discussion in the field and this idea possesses as many advocates as adversaries who have many arguments propagating their point of view. It is however worth to remember that for the time being, Turkey plays the role of an applicant towards the EU and can win more than lose while accessing the EU rather than while choosing another option, but it does not mean that such situation will last forever. Functioning at the clash of cultures, hurt by long expectation for 
"Western grace", Turkey may turn towards the second "natural" option - radical Islam and become another country generating threat to European security.

Last but not least problem is the EU's lack of self-reliance as far as energy supplies are concerned, which are gained from geopolitically sensitive regions like Russia, Middle East, Central Asia and West Africa. Taking into consideration the fact that energy production is perceived as political and economic power prerogative, and growing demand for energy sources of the developing economic powers such as China or India, the EU should consider energy security as one of key elements of the common foreign and security policy (Zaborowski, 2008). This debate is even more difficult with the diversity of approaches towards nuclear energy and using it by the civil sector (threat of uncontrolled proliferation). The problem of diversification of supplies as well as distribution is quite similar - this area also lacks coherence. Most EU member states realize bilateral agreements, taking care about national interest, which is not always parallel to other EU countries' interests ${ }^{4}$. It seems that the only possibility for the EU is to create internal energy market (including the necessity to build connections ensuring all member states access to the distribution network) and establishing unified and trustworthy external energy policy. Thus, there exists a necessity for intensive R\&D and technology cooperation, whose results would lead towards enlargement of existing energy sources' effectiveness and would create an alternative for fossil fuels.

${ }^{4}$ A good example is the one of the North gas pipeline - Russia and Germany agreed in 2005 upon building the pipeline via the Baltic Sea, omitting Poland. According to the agreement, the pipeline was to start functioning in 2010 and deliver gas directly from Russia to Germany. It was justified with the claim that the pipeline would increase energetic security of the whole Europe. 


\section{COOPERATION WITH THE UNITED STATES AND NATO}

Cooperation of the USA with the EU seems to be a natural sequence of the changes which took place in the world in the last twenty years. As it is emphasized by Zbigniew Brzeziński (2008: 157), "separately, and especially dissented, they are a guarantee of stagnancy and disorder". One could even risk a thesis that with the lack of close cooperation, there can appear escalation of conflicts, and the western model of democracy and free market economy may be replaced by other concepts of Muslim countries or quickly developing China or India. Unfortunately, the USA and the EU have not made an effort to institutionalize the cooperation within planning and foreign and defence policy so far. The United States expressed fear due to growing power of the EU under French and German leadership instead, and tried to suggest an alternative, which was welcome by Great Britain - an initiative aiming at creating a more "Atlantic" than "European" Europe (Brzeziński, 2008). The USA and NATO are perceived as a main guarantee for European security mostly by Great Britain, the Visegrad countries (mainly Poland), Spain (during Aznar's and Popular Party's government).

Unpopular as they still are in Europe, methods or strategies such as dissuasion, deterrence by denial and pre-emption are more often listed in security policy documents of the European countries ${ }^{5}$. Many European experts consider preventive war as contradictory to the international law, and those less strict claim that the authority of the UN Security Council must be maintained (UN resolution for such kind of intervention). The case

5 This issue is put forward in the French security policy, the military programme law for 2003-2008. This document states that: "The possibility of a pre-emptive action could be considered, as soon as a situation of explicit and known threat was recognised" (Yost, 2003). 
of Iraq showed that there is no consensus among the NATO member states over threat evaluation as well as problems solving methods. The greatest discrepancy appeared between the US and European positions, but also inside the EU there were countries favouring aggressive US policy. In order to build a real "Western power", cooperation between the EU and the US which would focus on coordination of undertaken actions and defining basic political and strategic goals and priorities is crucial. Preventive operations are not in favour of Europe with France and Germany being the main opponents. In case of Germany, such approach is connected with denial of power policy employing military means and favouring further development of European cooperation and promoting disarmament and arms control policy (Medeński 2003: 29-30). France on the other hand, seeks an alternative for the US policy, aiming at reestablishing its own European power and strength. Thus, Germany became a natural ally in these aims. Both countries try to promote Europe's capabilities in autonomy to the USA, not excluding cooperation, but cooperation based on parity not supremacy of one of the parties (in this case of the USA). Nowadays however, Germany emphasizes the necessity to put the Common Security and Defence Policy (CSDP) into transatlantic frames.

American doubts about independent European security pillar were caused by the fear of diminishing role of NATO, which, according to critical approaches, was reduced after the end of the bipolar division of the world. With the lack of a concrete adversary, NATO did not work out an alternative development strategy, so it lost most of its rationale. In a way, a very well known 3D ${ }^{6}$ rule created by Madeleine Albright is still valid. Certainty, NATO proponents as well as CSDP advocates realize that the only reasonable solution is close cooperation between both

${ }^{6}$ No duplication of what was done effectively under NATO, no decoupling from the US and NATO, and no discrimination. 
organizations and supporting common operations not competition. Unfortunately, in practice (it is especially evident during missions and operations) it is very often the case that both organizations put much effort in gaining own success instead of acting for common "added value".

In joint declaration signed in 2002, the EU and NATO agreed upon six priorities based on effective consultations and cooperation, equality and acknowledgement of autonomy of decision making processes and interests of both organizations as well as coherent and supportive military capabilities requirements system. As far as institutional issues are concerned, the partnership was confirmed by the Berlin Plus Agreement (March 2003) which permits the EU to use NATO structures, mechanisms and assets to conduct military operations in case when NATO rejects to do so. As there was also signed an agreement concerning the exchange of information between the EU and NATO, the EU possesses liaison offices in $\mathrm{SHAPE}^{7}$ and $\mathrm{NATO} \mathrm{JFC}^{8}$ in Naples. At that time, there also appeared a famous phrase describing the relation between the EU and NATO forces - separable, but not separate, which means that in practice, the same forces and capabilities will constitute a base for the EU and NATO actions, but their part may be allocated to the EU if necessary. In case of missions, there is the right of first refusal, which means that the EU may operate only if NATO rejects to do so. The above analysis shows that as far as the operational capabilities are concerned, the EU is still dependent on NATO even though is now possesses greater capabilities than it used to have e.g. during the Balkan conflict.

The New NATO Secretary General, Anders Fogh Rasmussen, during his speech on the first press conference concentrated on NATO priorities for the upcoming years (Afghanistan, NATO-

${ }^{7}$ Supreme Headquarters Allied Powers Europe.

${ }^{8}$ NATO Joint Force Command. 
Russia relations, cooperation with the Mediterranean Dialogue countries and Istanbul Cooperation Initiative, Kosovo issue and new NATO strategic concept ${ }^{9}$ ). At the end, he emphasized that the key issue is a close cooperation with the EU, thanking France for returning to the NATO military command structure at the same time. The whole part concerning the EU was presented in the French language, which, apart from being a courtesy act towards France, is a clear signal that full membership of France in the Alliance is of great importance, as it can be a notion of greater engagement in this direction instead of the CSDP, which will probably be hardly the case.

\section{THE MIDDLE EAST}

The main institutionalized tool (and practically the only one apart from the European Neighbourhood Policy) of the EU policy towards the Middle East is the Euro-Mediterranean Partnership, also known as the Barcelona Process ${ }^{10}$ established in 1995. This partnership is based on cooperation in three main areas: politics and security (establishing stability and security zone), economy and finance, and social and cultural issues (human resources development, intercultural understanding promotion). The priority goal of the Partnership is endorsement of long-term stability through economic development and liberalization which are to be gained via creating more work places, rising the life level and diminishing extremist ideologies attractiveness (Antczak, 2009). The above analysis shows that Europe, promoting stability, se-

9 Anders Fogh Rasmussen, NATO Secretary General during press conference on 1 August 2009 in Brussels, NATO website www.nato.int, 3.08.2009.

${ }_{10}$ Barcelona Process includes 38 countries: 26 EU member states and Algeria, Egypt, Israel, Jordan, Lebanon, Libya, Mauretania, Morocco, Palestinian Autonomy, Syria, Tunisia and Turkey. 
curity and democracy, concentrates mainly on economic support in order not to be so attractive to illegal immigrants who are perceived as a threat source. Nevertheless, economic support for the Maghreb countries may contribute to growing stability in the region and rising the overall security level.

During the EU summit in Paris in July 2008, the Union for the Mediterranean or the Mediterranean Union ${ }^{11}$ was established. It consists of 43 countries $^{12}$ and aims at strengthening the Barcelona Process through realization of concrete projects such as: water policies (water supplies and its accessibility are huge problems for Maghreb countries, which is often ignored by European states), transport (including sea transport) betterment ${ }^{13}$, countering sea pollution ${ }^{14}$ and fires, academic cooperation as well as political, security, social, cultural and humanitarian issues. The new forum is to prove that despite contradictory interests and multidimensional quarrels, cooperation is possible and it is even indispensable. While the Barcelona Process allows for unequal treatment of the non-European countries of the Mediterranean Sea, the Union for the Mediterranean was established basing on the equality rule, which can be perceived as an encouragement and a beginning of a real stabilization and democratization process (Larrabee, Green, Lesser, Zanini, 1998: 32-33). Unfortunately, the EU did not work out any policy towards the Israeli-Palestinian conflict nor Islamic fundamentalism within the Partnership and its Middle East peace process input is not spectacular. It is

11 Taking into consideration the character and the range of the activities of this forum, the name Union for the Mediterranean seems more appropriate.

$1227 \mathrm{EU}$ member states, non-European countries participating in the Barcelona Process (apart from Libya) and Albania, Bosnia and Herzegovina, Croatia, Montenegro and Monaco.

${ }^{13}$ There was established a plan of a motorway from Sinai to Casablanca the EU wants to gain private investors to sponsor.

${ }^{14}$ The project includes building at least 45drain refineries in Maghreb countries. 
also worth to analyze the adequacy of employing the same policy towards all Maghreb countries. It is not about unequal treatment, but differentiated approach towards various problems, as each country deals with a bit diverse problems is at different economic development stage, and political situation varies significantly. Sometimes, requirements (equal) stated by the EU are so high that some countries are not able to meet them (e.g. introduction of the Value Added Tax in Lebanon), which may cause discouragement and search for other "tutor" than the EU.

Similarly to the United States, even though in smaller dimension, European countries pay much attention to Israel - especially in the field of research and technology cooperation and working out the means of countering terrorism. However, the victory of Hamas in Palestinian Autonomy elections in 2006 caused extension of the stabilization process in Iraq and influenced the development of Iranian nuclear program. For these reasons, the EU has taken up broader discussions about the necessity of working out a common strategy for the Middle East conflicts. It also means radicalization of policy towards Palestine if it violates peace rules and Israel which is required to accomplish sovereignty of Palestine. The role and meaning of the EU in the peace process in the Middle East is gradually growing and despite economic support for the Palestinians, still the US possess the exclusive mediatory function and there are no premises for a change in the nearest future. In spite of difficulties, the EU succeeded in working out a consensus towards the main directions of the CSDP Middle East policy and managed to establish a distinctive international identity, despite insubordination of some countries, mainly France (Soetendorp, 2002: 294-295).

War in Iraq showed that it is crucial for the US and the EU to work out a compromise acceptable by both sides of the IsraeliPalestinian conflict. Unfortunately, the US intervention in Iraq deepened the discrepancy between the European and American vision of conflict solving (although especially France and Ger- 
many opposed the operations at the beginning, the EU countries finally engaged in the stabilization operation in Iraq when they revealed all economic and political profits - gaining influence and possibility to co-decide). The United States concentrate their efforts mainly on controlling the Israel-Palestine agreement to be profitable for their interests (political influence and oil access). Rigorous position of the USA, which can lead to the loss of influence in the Middle East in future, causes that Europe does not want to identify fully with such policy realizing that China is equally interested in gaining influence in this region, mainly due to the desire to possess access to oil (Brzeziński, 2008: 171180). Muslim countries' hatred directed at America may result in turning towards China (search for a strong protector), which is why the EU tries to conduct its own policy in this region, not necessarily equal to the one of the US.

\section{ASIA}

Effective eastern policy seems to be crucial for the EU. The conflict in Georgia showed weakness of the EU and its conflict prevention policy mechanisms. In this dimension, Caucasus appeared to be a repetition of the situation which took place in the Balkans. While Russia returned to the power policy, the EU has little to offer within its Neighbourhood Policy employing only soft power and promises, and putting forward relatively low financial support while compared to the threat of gas supplies restrain (e.g. the case of Ukraine). The EU has to learn how to find such means which would constitute an effective counterbalance for Russian intimidating policy conducted in former soviet republics in Europe and Asia.

Asia is generally perceived as an economic challenge for Europe - on the one hand, there exists a threat of conquering the European market by cheap Chinese and Taiwanese products, 
and on the other - it is a market requiring European investment and technology. China and the EU regard themselves as mutually complementary elements on international scene (economically and politically - gaining influence in concrete regions of the world). Thus, the EU as well as China are interested in maintaining stability in the world and establishing effective multilateral mechanisms. Europe has the chance for close cooperation with China in the field of science and technology, therefore it is European interest to promote stability in China. France also tries to tighten cooperation with India and is an advocate of its accession as a constant member to the UN Security Council and favours broadening of the G8 Group for India. It is caused by economic interests of the armament sector $(80 \%$ of weapon and materiel purchased by India comes from France). Close cooperation with newly born economic powers seems to be also the only chance for Europe to remain on the scene of the most important international affairs, a kind of "control" dealing with possessing knowledge about the competitor.

If the position of the USA weakens (mainly due to bad relations with the Muslim countries), it will act in favour of the growing power of China (Brzeziński, 2008: 175-176). For these reasons, Europe should establish closer cooperation with dynamically developing Asian countries, especially with Eastern Asia. The EU should play the role of a lighthouse in Asia. It is important to promote democracy and free market rules implementation, as such political and economic system (properly functioning) is a guarantee of security. The EU encourages China (but also other countries) to derive as much as possible from political and economic culture of the EU. In order to serve as a model, the EU has to deepen its knowledge about complex process taking place in the region. Great expectations of the southern Asia towards the EU were in a way failed. Therefore, now eastern Asia does not want to make similar mistake and is waiting for the EU's evolution towards greater understanding for the situation in the 
region, and concrete political and economic involvement (the effects) of the EU as a whole (especially in the $\mathrm{ASEM}^{15}$ and $\mathrm{ARF}^{16}$ ), showing activeness in such areas as: security, weapon of mass destruction non-proliferation policy and counterterrorism. The EU has to compete for greater access to the Asian markets and use its significant superiority of technological advancement.

From the political point of view, the EU should conduct a determined policy and observe patiently the direction of ChineseJapanese relations and the way the Taiwan issue will be finally solved, and present huge flexibility in these matters. The EU may promote multilateralism encouraging to use its broad experiences in the field, employing the soft power.

The report for the European Commission External Relations Directorate General identifies accurately five key recommendations for the EU in relation to Eastern Asia (van der Geest, Benini, 2005):

- effective projecting of the EU soft power;

- support for the emerging multilateralism in East Asia;

- strategize cooperation with China;

- keeping "culture" central in developing interregional relations;

- building-up analytical capability to engage with Asia.

\section{AFRICA}

Since the terrorist attack on the United States in 2001, one of the greatest concerns of the international society have been the failed states which are easy influenced by international terrorism. Africa is a continent of greatest number of politically and

15 ASEM-Asia-Europe Meeting-informal dialogue and cooperation process between the EU and East and South-East Asia iniciated in 1996 in Banghkok.

${ }^{16}$ ARF - ASEAN Regional Forum. 
economically weak countries, therefore they are receptive to such kind of issues. This is the reason why the EU is interested in keeping stability in this region. Failed states generate such problems as refugees, illegal immigrants, pandemics, humanitarian catastrophes and organized crime, which are most often directed at Europe. Moreover, there live over two million EU citizens in these countries, especially from Great Britain, France and Portugal, who has the right for aid and protection ${ }^{17}$. The growth of oil prices and other energy resources as well as problems connected with illegal immigration from different African countries contributed to the increased interest in this continent. It is also connected with the colonial history and a kind of guilt and responsibility the European countries feel towards Africa. This issue has other dimension as well, namely implications connected with colonization, meaning particular interests of European states or even neocolonialism notions - such allegation concerns mainly France and Belgium.

Relations between European and African countries have always been characterized by asymmetry and dependence the latter on the policy of the former. Cooperation had been concentrated on economic aspect for many years ${ }^{18}$ with the African countries being most often the recipient, which caused their dependence on strong and powerful European states, which in turn used the "stick and carrot" method $^{19}$ deepening the dispro-

17 This is the reason why many military operations were also aimed at rescue and evacuation. Establishment and specificity of the European Battle Groups was also an effect of challenges the EU faced during operations in SubSaharan Africa (Pabst, 2008).

18 The EU (former European Economic Community) has a long history of preferential trade with African countries - establishment of the European Development Fund in1958 and Yaoundé convention from 1964 concerning trade agreement between the EEC and 18 postcolonial African countries. Nowadays, the EU is the most important trade partner for the Sub-Saharan Africa.

${ }^{19}$ Financial aid was dependent on African countries observance of human rights and democratic rules of governance. Otherwise, it was limited, suspend- 
portion of relations. Another issue is using double standards by the EU towards its African policy when geopolitical and economic interests come into play (especially energy resources). The EU should change its attitude towards African countries policy from foreign affairs object to active subjective treatment, in which short-term economic goals will not cover these longterm perspective leading towards strategic partnership. This path seems, however, to be very long as Europe still treats Africa as a source of certain goods to be used and to give in turn as little as possible so as to keep the "source" alive. Research conducted by the UN showed that aid in terms of development had positive impact on economic growth while the geopolitical aid negative or in the best case neutral (Reddy, Minoiu, 2006). Thus, significant effort is put into combining assistance in the field of governance, democracy, human rights and the rule of law. Unfortunately, introduction of the political element to the European aid program caused even greater asymmetry of the mutual relations at the same time (Schieder 2008: 21). On the other hand, the EU does not let African countries enter its comestible market. Protectionist agriculture policy of the EU causes that African products are not competitive on the European market ${ }^{20}$.

In December 2005 there was introduced a first political-strategic document defining European-African relations. Only 7-page long document identifies five main areas of cooperation: peace and security, human rights and governance, development, economic growth, and regional integration and trade as well as

ed or liquidated (temporarily or entirely).

20 This is the reason why African countries call for ceasing such EU policy, as it prevents African countries from maintaining their economies. Nevertheless, protectionist policy is dictated by a strong agricultural lobby inside the $\mathrm{EU}$, which means a definite contradiction of interests, and the EU having to chose between protecting its own agriculture and opening the market for Africa, helping the countries to develop their economies, will always chose its own good. Finding a good solution may be extremely difficult. 
human resources investment ${ }^{21}$. Just after issuing the document, the EU has launched three important initiatives: establishing the EU-Africa Infrastructure Partnership in June 2006, the EU Governance Initiative in August 2006, and in October 2006 the EU implemented the Support Programme to the African Union ${ }^{22}$. Since 2004, the EU has been supporting the African Union (AU) in the field of maintaining peace and security by financial and logistic support, long-term capabilities building and short-term military power supply. Using the European Development Fund, the African Peace Facility was established and civilian specialists offered aid within consultations, planning and training for the African Union mission in Sudan between 2004 and 2007 (Pabst, 2008: 36). The second EU-AU summit in December 2007 concentrated mainly on Zimbabwe and violation of human rights. African countries showed ambivalent attitude towards this issue, which was unacceptable for the EU. Nevertheless, despite these discrepancies, the Africa-EU Strategic Partnership ${ }^{23}$ was established as well as the first Action Plan for the years 2008-2010 and energetic partnership was recognized ${ }^{24}$.

Missions and operations conducted by the EU in Africa are by far caused by the responsibility factor of the European states for their former colonies. Thus, there are conducted humanitarian and peace support operations, but they are too ad hoc and motivated by concrete political and strategic interests. Such behaviour is justified by the following reasoning: definite destabilization of Africa is undesirable as it would cause the flow

21 The EU and Africa: Towards a Strategic Partnership, Council of the European Union, Brussels, 19 December 2005.

${ }^{22}$ For further information see S. Schmidt, Towards a New EU-African Relationship - A Grand Strategy for Africa?, "Foreign Policy in Dialogue", vol. 8, issue 24, Trier, 19 June 2008, p. 13.

23 This document defines frames for the strategy of 2005.

${ }^{24}$ International company "Total" (of French origin) is the biggest oil producer in Africa and 30\% of the overall production comes from Africa. 
of immigrants and stimulate illegal weapon and drugs trade, international terrorism and make the region easily receptive to orthodox Islam.

Missions in Congo and Chad, aiming at reestablishing stability and security in the region, are supported mainly by France due to historic factors reaching the colonial times, but also economic interests - natural resources (including oil). Critics claim that especially the mission in Congo was "a political manifestation of France and Germany ${ }^{25}$ which, in the time of the EU crisis, were trying to prove that the CSDP was developing dynamically" (Górka-Winter, 2006). Chad is also an area of French interests - rivalry with Libya for gaining profits in "traditional" zone of influences ${ }^{26}$. The biggest EU countries - Great Britain, Germany and Italy refused to send their troops to Chad, possibly due to the risk of too evident breaking of the EUFOR neutrality rule. The mission in Chad, owing to the weak UN mandate, small amount of soldiers and equipment had little chance for success also in the humanitarian dimension. It is very probable that the EU intervention in Guinea-Bissau was caused by the fact that $43 \%$ of citizens are Muslims and in the last few years started to function Columbian cocaine cartels, which constituted a dangerous combination resulting potentially in this country joining other ones generating international terrorism, which is why the there was established the EU Mission in Support of Security Sector Reform. Thus, there immediately comes the question if now comes the time for Somalia or Liberia? In Somalia (country established by joining British Somaliland and Italian Somaliland), there are many natural resources including oil. The exploitation is prevented by the lack of financial means, transportation possibilities, water as well as internal instability. Similar situation

${ }^{25}$ Many experts claim that Germany will want to play greater role in international politics (Pietrzak, 2001).

${ }^{26}$ France supports potentates in this country. 
is noted in Liberia (the region of rivalry for influences between America and Europe), but these countries are perceived as a great challenge. Political and economic situation is much worse than in other regions of Africa, and these countries do not possess as strong historic connections with one European state as Chad or Congo with France, which is why no European state tries to restore their area of influence. It would be profitable to create a three-party cooperation in the field of security between the EU, UN and AU. It is crucial to establish the common EU vision of African policy which would go over narrowly perceived national interests of some EU countries (Vasconcelos, 2007: 10) ${ }^{27}$.

For the EU, cooperation with South Africa Republic, the most prospective country of the African continent, is also of special importance - in May 2007 there was implemented an agreement on strategic partnership ${ }^{28}$. It assumes closer cooperation in the field of economy and finance (trade and investment, $R \& D$ projects and technology development) as well as establishing new areas of mutual interest (environment protection - climate changes, education and training, sport and recreation, culture, IT systems and macroeconomic dialogue). The EU also offers the possibility of using its experience in terms of regional policy and social problems solving (unemployment, social issues and countering delinquency).

The growth of the EU interest in Africa caused also the growth of importance of the latter on the international arena. The continent became an object of interest of China (especially economic issues - Africa cannot afford expensive European product, therefore becomes an ideal market for competitive Chinese product ${ }^{29}$ )

${ }^{27}$ It is the opinion of the EU Strategic Studies Institute director.

28 The South Africa-European Union Strategic Partnership Joint Action Plan was signed on 14 May 2007 in Brussels.

${ }^{29}$ A good example of the EU fear of the African market being floated by Chinese products is European-African infrastructural partnership. 
and the United States (limited almost entirely to oil production and countering Islamic terrorism, and apart from Liberia, other countries did not react positively towards American attempts of domination in the region). Thus, the $\mathrm{EU}$ is no longer the only and "natural" partner of Africa, which means that the growing interest in this continent may be equally caused by the increased competition for influence in Africa and access to its resources. Such situation caused a kind of awakening of the EU as far as the policy or even strategy towards Africa is concerned. The EU also aims at persuading the African countries to favour the overall directions of its global policy in the field of politics, finance and environment considering the African presence in international institutions.

The EU supports the African preventive diplomacy ( $\mathrm{Zi} \mathrm{ba,}$ 2005). It understands that the AU needs a strong partner and geographic vicinity as well as historic and political-economic factors make the EU the best candidate. Nevertheless, these relations are traced by the African threat of too strong engagement of the former colonial powers. Some member states are still behaving in an imperialistic manner and are trying to redirect the EU policy so that it fits their national interests (such situation takes place mainly in case of French and Belgian policy towards the Sub-Saharan Africa). On the other hand, the EU draws its power from diversity and variety of possibilities in terms of political, economic and institutional solutions using the experience of its member states. Thus, it is a paradox that the issue which decides about the European power is its greatest weakness at the same time. Africa is the possible region for the EU to be the most important partner (especially that the presence of European influence in the region dates six centuries back) therefore, it should intensify the efforts in this direction. Other geopolitically important regions of the world belong to the US influence zone (Middle East) and apart from the necessary presence, the EU will never be an equal partner of the US. 
Summing up, it seems that main threats for Europe will derive from globalization and results of concentration on consumption. Aging European society will generate economic slow-down (reduced NGP), which will additionally increase aggressive entrance of Chinese products on world markets. The demographic factor will act as a disadvantage for Europe - the flow of immigrants from Asian and African countries will generate assimilation problems and may also cause increase of delinquency, organized crime and easier terrorist nets establishment (Howorth, 2007). The EU has a potential and possibilities which are not property used due to its unconcern and too high level of bureaucracy. The "starting the engine" process lasts too long, but on the other hand, the EU is interested in creating a real "added value" of its foreign policy while compared to other players on the international arena (Grevi, 2008).

Another challenge for Europe is energetic security and access to resources, the demand is still growing for, especially coming from quickly developing economies such as China, India or Brazil. This issue is connected with environment pollution and climate change which are becoming more and more important problems, as weather anomalies are the reason of many catastrophes. As far as defence issues are concerned, the nearest future does not seem to bring any greater changes. A problematic issue of the Middle East, post-soviet countries and Sub-Saharan Africa will remain as well as a priority of cooperation with NATO (which is almost equal with the USA) towards building world stability. The EU will be also concerned with the EU enlargement (Turkey and other countries in further perspective) or building a kind of close association with these countries, or much more institutionalized partnership with the North African countries and non-orthodox Muslim countries. The next important issue is the one of security policy planning, and establishing strong defensive capabilities (including contingency planning), which will be connected with possible new CSDP missions and opera- 
tions (most probably mainly in Africa), so that Europe becomes a more and more independent strategic player, which is crucial in case of discrepancy between the US and the EU priorities.

The EU tries to play a more significant role in the peace process in the Middle East and intends to strengthen its influences in the region, being a rival of the USA. It is possible that the USA will gradually withdraw from the region aiming at greater engagement in south-east Asia. Better image of the EU than the US among the Middle East countries works also in favour of Europe and its soft power policy. The EU with the UN, USA and Russia has constituted the so called Middle East Quartet since 2002, which means that it participates actively in solving the Palestine-Israel conflict.

Finally, it is worth to analyze potential options of the geopolitical situation evolution and its implications for Europe. The most basic issue is creating a real unity within the EU which will not be mainly an economic union. It seems that nowadays, the EU has to conduct a real, effective and coherent foreign and security policy as to maintain the role of important international player. Otherwise, it will be marginalized and reestablishment of the empire prerogatives may be unreal. It seems obvious that it will not be supported by the US till they are able to play a crucial role in the world absolutely independently. The EU is perceived as a competition, even though such approach appears to be shortsighted, as developing political and economic powers (China, India) will play greater role in the world and will also aim at strengthening their position through tightening cooperation, establishing international interdependencies and institutionalizing them. Maintaining the "Western hegemony" in the world, if it constitutes the main goal of American and European efforts, has to be a common effort.

It also seems that it is the European interest to cooperate closely with Russia, which constitutes a kind of counterbalance for China, and weakened by internal conflicts as well as poor 
economy, becomes dangerous on the one hand (possibility of destabilization), and may cause loss of balance on Asian continent leaving China open door for full domination.

The shift of American policy from Europe towards south-east Asia means at least a few implications for Europe: marginalization of its position, but also greater distance from potential conflicts. Only tightened cooperation with China and so called Asian Tigers may save Europe from losing importance on the international scene. Greater distance from conflicts will allow for further development and possibility of possessing bigger input into the peace process through Petersberg tasks realization within the CSDP. Effective EU operations on the one hand will grant prestige, and enlarge the range of influence on the other. The EU may also compete for the mediatory role in many conflicts not engaging directly or standing at one of the sides as it is often the case of the US (combined with hard power policy which does not act in favour of the USA). The EU, opting for soft power, may constitute an interesting alternative to the US policy towards Asia and the Middle East as it should not let the US dictate and entirely dominate the south-east Asian policy.

It is very probable that Europe will remain closely connected with the African continent - not to lose its traditional region of influence as well as for the reason that it is the area where its policy may lead primacy. Thus, the EU should not leave the region open for the US whose interests are quite different from the European mainly due to geographic location. Africa is not only a source of oil for Europe, but also it is a region which destabilized, may influence negatively the European security level. Obviously, Europe is interested in supporting African countries in terms of stabilization and development, but only as much as they do not generate problems which could affect Europe negatively. Generally, it is desirable to maintain the status quo as far as the reliance of most African countries on European aid causes a new kind of "vassalization", colonization of the XXI century - 
financial and economic dependence practically means a kind of political dependence.

The last issue is further broadening of the EU - accession of Balkan countries, then other eastern Europe countries (the area of influence of the former Soviet Union, especially Ukraine) and Turkey, and in longer perspective - non-European states (e.g. the Middle East). It seems that in a geostrategic aspect, including more countries into the "Western model" is a guarantee for broadening the EU influence zone and establishing a greater political, economic and social interdependent network, which seems to be a similar policy to the one towards Germany after the World War II. Looking at this issue from the security perspective, only binding these countries to the EU is a guarantee for stability (otherwise, these states may turn to Russia in case of Eastern Europe, or Muslim countries in case of all other states). Such situation would cause a threat for the EU of limiting influences and escalate the West-Islamic fundamentalism conflict. On the other hand, accession to the EU of such culturally, politically and economically distant countries evokes questions about the future of the European unity - would it be still possible to gain consensus concerning issues that particular national interests seem impossible to be brought together.

Europe has a few possibilities as far as its own shape as well as its strategic priorities are concerned. Enlargement of the EU for Western Balkans (firstly Croatia and Macedonia) seems to be a natural solution. In the next phase, accession of other countries of the region is probable as well as Turkey and Ukraine. There is an open question about Europe's evolution towards confederation, which seems to be a likely scenario in the far future, even though it is not very real at the time being, mainly due to long lasting bureaucracy mechanisms of the EU. Lack of dynamics of the European policy has been visible for the nineties of the XXth century, and broadening of its structures for new countries did not bring the expected effect of "freshening", or at least the fresh 
blow was too small to wake up political elites of the "old" EU countries from lethargy. The EU's attitude towards closer cooperation with Maghreb countries and search for institutionalization of these relations (a kind of association, common market or cooperation only) is also unknown. All answers to the above questions will determine significantly the definition of the EU foreign policy (if it exists) priorities. The EU may decide to concentrate on the closest geostrategic environment - will focus on maintaining the greatest influence in Africa and will try to gain significance in the Middle East arena (it is much dependent on the EU's strength while compared to the USA and its offer for the Middle East countries), or it will try to face the challenges of the new south-east Asian powers. The least probable variant is more intense interest in cooperation with Latin America which in short and Middle-term perspective will remain on a similar intensity level.

\section{REFERENCES}

Antczak A. (2009), The Mediterranean dimension of Spanish national defence policy,

"Defence and Strategy" No 1/2009, Strategic Studies Institute of Brno Defence University.

Brzeziński Z. (2007), Second Chance: Three Presidents and the Crisis of American

Superpower, Basic Books, New York 2007 (the author used the Polish language version, Warsaw 2008).

Geest W. van der, Benini R. (2005), The European Union's Strategic Interests in

East Asia; Study on the economics and politics of East Asian Cooperation and in particular China's role in this process: Challenges and Opportunities for EU Policy; European Institute for Asian Studies, Brussels.

Górka-Winter B. (2006), Misja Unii Europejskiej w Demokratycznej Republice Konga, "Biuletyn PISM" No 44, Warszawa.

Grevi G. (2008), The EU and global governance: rules, power and priorities, Rome. Howorth J. (2007), Security and Defence Policy in the European Union, Palgrave Macmillan. 
Huntington S. (1996), The Clash of Civilizations and the Remaking of World Order, Touchstone, New York (the author used the Polish language version, Warsaw 2003).

Kapuściński R. (2007), Rwący nurt historii, Wydawnictwo Znak, Kraków.

Kolodziej E. (2005), Security and International Relations, Cambridge University Press, Cambridge.

Larrabee S., Green J., Lesser I., Zanini M. (1998), NATO's Mediterranean Initiative: Policy Issues and Dilemmas, RAND Monograph Report.

Medeński M. (2003), Polityka bezpieczeństwa Niemiec w świetle zagrożeń terroryzmu międzynarodowego, Wydawnictwo Adam Marszałek, Torun.

Pabst M. (2008), Building Peace and Security - An Assessment of EU Efforts of Capacity-building and ESDP Operations in Sub-Saharan Africa, "Foreign Policy in Dialogue", vol. 8, issue 24.

Pietrzak P. (2001), Polityka bezpieczeństwa zjednoczonych Niemiec, Wydawnictwo Adam Marszałek, Toruń.

Reddy S., Minoiu C. (2006), Development Aid and Economic Growth. A positive Long-Run Relation, "DESA Working Paper" No. 29.

Schieder S. (2008), Trade and Development in EU-Africa Relations, "Foreign Policy in Dialogue", vol. 8, issue 24.

Schmidt S. (2008), Towards a New EU-African Relationship - A Grand Strategy for Africa?, "Foreign Policy in Dialogue", vol. 8, issue 24.

Soetendorp B. (2002), The EU's Involvement in the Israeli-Palestinian Peace Process: The Building of a visible International Identity, "European Foreign Affairs Review", vol. 7, issue 3.

Vasconcelos A. de (2007), Security for Africans, "ESDP Newsletter" No. 5.

Yost D. (2003), Debating security strategies, "NATO Review".

Zaborowski M. (2008), A common approach to the neighbourhood, Institute for Security Studies, Warszawa.

Zięba R. (2000), Europejska Tożsamość Bezpieczeństwa i Obrony, Wydawnictwo Naukowe SCHOLAR, Warszawa.

Zięba R. (2001), Instytucjonalizacja bezpieczeństwa europejskiego, Wydawnictwo Naukowe SCHOLAR, Warszawa.

Zięba R. (2005), Wspólna polityka zagraniczna i bezpieczeństwa Unii Europejskiej, Wydawnictwo Sejmowe, Warszawa.

Zięba R. (2008), Bezpieczeństwo międzynarodowe po zimnej wojnie, Wydawnictwa Akademickie i Profesjonalne, Warszawa. 